\title{
URGENSI KOLABORASI RISET DALAM RANGKA ALIH TEKNOLOGI PENANGGULANGAN COVID-19
}

\author{
${ }^{1}$ Angga Wijaya Holman Fasa, ${ }^{2}$ Mahardhika Berliandaldo \\ ${ }^{1}$ Lembaga IImu Pengetahuan Indonesia, Jl. Jenderal Gatot Soebroto Kav. 10, Jakarta, \\ e-mail: awijayahf@gmail.com \\ 2Lembaga IImu Pengetahuan Indonesia, Kawasan CSC-BG LIPI, \\ e-mail: aldo.vega17@gmail.com
}

\begin{abstract}
The coronavirus respiratory syndrome (COVID-19) pandemic has become a global public health problem. One of the main efforts to overcome this problem is research and development of technology in the health sector. This condition requires the readiness of the State Civil Apparatus (ASN), especially researchers and engineers, to increase the capacity or competence through technology transfer mechanisms in research collaboration schemes, both at the national and international levels. This study aims to find out, understand and explain two things, the urgency of research collaboration in the context of transferring COVID-19 countermeasures technology and strategic efforts to build research collaboration. This study uses a qualitative method with a descriptive analytical approach. The results of the study shows two things, first, that research collaboration in the context of technology transfer is significantly urgent to be implemented in order to encourage researchers and engineers to gain new knowledge about technology in the health sector, and second, strategic efforts that can be implemented by collaborating with researchers and engineers of credible research institutions in the health sector, and have implemented an open science policy which will significantly assist the technology transfer process without being constrained by intellectual property issues.
\end{abstract}

\section{Keywords: COVID-19; Intellectual property; Open science; Research collaboration; Technology transfer}

\begin{abstract}
Abstrak
Pandemi sindrom pernafasan virus corona (COVID-19) telah menjadi permasalahan kesehatan publik global. Salah satu usaha utama dalam rangka penanggulangannya adalah riset dan pengembangan teknologi di bidang kesehatan. Kondisi ini membutuhkan kesiapan Aparatur Sipil Negara, khususnya para peneliti dan perekayasa, untuk meningkatkan kapasitas atau kompetensi riset dan pengembangan teknologi di bidang kesehatan. Salah satu cara peningkatan tersebut adalah melalui mekanisme alih teknologi dalam skema kerja sama riset, pada level nasional maupun internasional. Studi ini bertujuan untuk mengetahui, memahami dan menjelaskan dua hal, yaitu urgensi kolaborasi riset dalam rangka alih teknologi penanggulangan COVID-19 dan upaya strategis dalam rangka membangun kolaborasi tersebut. Studi ini menggunakan metode kualitatif dengan pendekatan deskriptif analitis. Hasil studi menunjukkan dua hal, pertama, bahwa kolaborasi riset dalam rangka alih teknologi signifikan urgen untuk dilaksanakan dengan pertimbangan bahwa dengan adanya kolaborasi riset dapat mendorong para peneliti dan perekayasa mendapatkan pengetahuan baru mengenai teknologi di bidang kesehatan, dan kedua, upaya strategis yang dapat dilakukan adalah dengan cara berkolaborasi dengan para peneliti dan perekayasa institusi riset yang kredibel dalam riset dan pengembangan teknologi di bidang kesehatan, dan telah menerapkan kebijakan open science yang mana akan sangat membantu proses alih teknologi tersebut tanpa terkendala masalah kekayaan intelektual.
\end{abstract}

Kata Kunci: alih teknologi; COVID-19; kekayaan intelektual; kolaborasi riset; open science

Open Access at:http://ojs.uho.ac.id/index.php/PUBLICUHO/index

Journal Publicuho is licensed under a Creative Commons Attribution 4.0 International License. 


\section{Journal Publicuho}

ISSN2621-1351 (online), ISSN 2685-0729 (print)

Volume 4 Number 3 (August - October), 2021 pp. 820-833

Accredited SINTA SK.NOMOR 28/E/KPT/2019

Open Access at:http://ojs.uho.ac.id/index.php/PUBLICUHO/index

DOI: $10.35817 / j$ pu.v4i3.19670

\section{PENDAHULUAN}

Wabah sindrom pernafasan virus corona (COVID-19) adalah masalah global. Pandemi ini merupakan keadaan darurat kesehatan publik yang menjadi perhatian internasional disebabkan implikasinya yang mengancam kehidupan dan kesejahteraan populasi dunia. Data mutakhir Organisasi Kesehatan Dunia (WHO) menunjukkan bahwa hingga bulan November 2020 telah tercatat 54.301.156 kasus dan angka kematian sebesar 1.316.994 jiwa (WHO, 2020). Sementara itu, di Indonesia, berdasarkan data yang dirilis oleh Satuan Tugas COVID-19 tercatat 470.648 dan korban jiwa sebesar 15.296 orang (Satgas-Covid19, 2020).

Permasalahan kemanusiaan ini membutuhkan upaya yang komprehensif. Salah satunya adalah menemukan atau menciptakan teknologi di bidang kesehatan. Mengingat rentang permasalahan yang bersifat global, dibutuhkan kolaborasi global sebagai solusinya (Campbell et al., 2020). Kolaborasi tersebut dapat berupa pendayagunaan jejaring riset di bidang Kesehatan. Penguatan kolaboratif ini dibutuhkan untuk dibangun antar institusi riset agar dapat mempertemukan atau menggabungkan kemampuan ilmiah atau invensi teknologi mutakhir, yang mana hasil riset kolaboratif tersebut pada gilirannya berkontribusi kepada pengembangan teknologi kesehatan, seperti instrumen diagnostik, vaksin, dan obat-obatan dalam rangka mengatasi keadaan darurat Kesehatan.

Bentuk kolaborasi tersebut tidak dapat ditangani oleh satu organisasi publik atau satu sektor kebijakan saja, melainkan membutuhkan tindakan kolaboratif dari berbagai organisasi di berbagai sektor kebijakan. Kolaborasi ini tercermin dalam bentuk praktik jejaring kolaboratif, dimana terdapat seperangkat pengaturan kerja integratif yang dinamis untuk mendorong kolaborasi antar institusi riset. Jejaring kolaboratif ini membentuk suatu interaksi untuk meningkatkan kondisi kesiapsiagaan dalam menghadapi kondisi krisis atau darurat yang berbasis ilmu pengetahuan dan teknologi.

Meskipun demikian, terdapat beberapa permasalahan fundamental atau esensial yang ditemui dalam konteks kolaborasi riset, antara lain hambatan kolaborasi muncul dari waktu pelaksanaan (time frame), pendanaan, birokrasi, budaya, sistem keuangan, etika, benturan nilai, jarak antara peneliti, kebijakan, dan psikologis yang berbatasan dengan kesediaan untuk berbagi (Maluleka et al., 2016). Faktor yang terakhir tersebut, kesediaan untuk berbagi, erat kaitannya dengan masalah pengaturan dan perlindungan kekayaan intelektual yang pada umumnya menjadi hambatan dalam pengembangan teknologi dalam kerangka kolaborasi riset. Dengan kata lain, permasalahan kepemilikan dari suatu teknologi yang dilindungi rezim kekayaan intelektual belum dalam posisi sebagai katalisator kolaborasi riset. Berdasarkan pembahasan di atas, maka terdapat permasalahan yang dapat dirumuskan sebagai berikut, pertama, urgensi kolaborasi riset dalam rangka alih teknologi penanggulangan COVID-19. Kedua, bagaimana upaya strategis membangun kolaborasi 
riset dalam rangka alih teknologi penanggulangan COVID-19. Kemudian tujuan riset ini terdiri atas 2 (dua) hal. Pertama, penulis hendak mengelaborasi urgensi kolaborasi riset dalam rangka alih teknologi penanggulangan COVID-19 sehingga didapatkan pemahaman yang utuh mengenai hal tersebut. Kedua, setelah mengetahui urgensinya kemudian dielaborasi lebih lanjut upaya strategis guna membangun kolaborasi riset dalam rangka alih teknologi penanggulangan COVID-19.

\section{METODOLOGI}

Penelitian ini menggunakan metode kualitatif dengan pendekatan deskriptif analitis (Bryman dan Burgess, 2002). Tujuan riset kualitatif adalah untuk menjelaskan dan menunjukkan pentingnya kedalaman dan detail suatu data yang diteliti berkaitan dengan obyek riset ini, yaitu untuk mengetahui, memahami dan menjelaskan urgensi kolaborasi riset dalam rangka alih teknologi penanggulangan COVID-19 dan upaya strategis dalam rangka membangun kolaborasi riset.

Data yang diperoleh dalam riset ini merupakan data sekunder. Pengumpulan data dilakukan melalui pengkajian literatur, dan dokumen yang relevan, serta menelaah data berupa keterangan yang berkaitan dengan obyek kajian. Data-data diperoleh melalui akses internet, penelusuran dokumen atau publikasi informasi.

\section{HASIL DAN PEMBAHASAN}

\section{Kolaborasi riset dan alih teknologi}

Kolaborasi riset secara konsisten memainkan peran penting dalam kemajuan pengetahuan dan meningkatkan relasi sinergis antara pemangku kepentingan berbasis pengembangan ilmu pengetahuan dan teknologi. Kolaborasi semacam itu terutama dilaksanakan dalam lingkup kegiatan alih teknologi, riset dan pengembangan Iptek. Kolaborasi riset juga dapat mendorong alih teknologi secara tidak langsung melalui peningkatan kualitas hasil riset. Hasil riset kolaboratif merupakan hasil penggabungan daya, cipta, dan karsa ilmiah dari berbagai institusi riset yang terlibat dalam kolaborasi riset. Sumber daya organisasi meliputi kekuatan basis riset dan infrastruktur komersial yang mendukung (Friedman \& Silberman, 2003). Kualitas hasil riset diartikan sebagai arti penting substansi pengetahuan yang terkandung dalam hasil tersebut, misalnya dalam konteks diperolehnya paten ataupun jenis Kekayaan Intelektual lainnya sebagai hasil riset.

Disebabkan kolaborasi riset menyediakan platform bagi para pemangku kepentingan untuk menghasilkan pengetahuan baru, maka dibutuhkan strategi kolaborasi yang efektif baik dalam hal berbagi sumber daya, maupun dalam menghasilkan, meningkatkan, dan mendayagunakan ilmu pengetahuan yang ada. Pengetahuan baru (tacit) berasal dari pengalaman langsung dari dalam institusi riset itu sendiri dalam fase sosialisasi (tacit-tacit) (Nonaka dan Toyama, 2007). Langkah selanjutnya, eksternalisasi (tacit-explicit), melibatkan 


\section{Journal Publicuho}

ISSN2621-1351 (online), ISSN 2685-0729 (print)

Volume 4 Number 3 (August - October), 2021 pp. 820-833

Accredited SINTA SK.NOMOR 28/E/KPT/2019

Open Access at:http://ojs.uho.ac.id/index.php/PUBLICUHO/index

DOI: $10.35817 / j p u . v 4 i 3.19670$

kombinasi individu dari masing-masing kelompok dan termasuk konversi pengetahuan (tacit) melalui dialog atau diskusi. Fase kombinasi (explicit-explicit) melibatkan organisasi dan penerapan pengetahuan eksternal (explicit). Dalam fase internalisasi (tacit-explicit), setiap pengetahuan baru yang dihasilkan dari proses kolaborasi institusi riset berimplikasi pada dua hal, yaitu dalam rangka mendukung hilirisasi hasil riset dalam kerangka alih teknologi, dan guna memperoleh pengetahuan baru untuk tujuan praktis dan pengembangan teori.

\section{Kekayaan intelektual dan open science}

Kekayaan intelektual didefinisikan sebagai: "segala hal yang mengacu pada curah gagasan pemikiran dalam bentuk ciptaan, seperti invensi di bidang teknologi; karya sastra dan seni; desain; dan simbol, merk dagang dan obyek visual yang digunakan dalam perdagangan" (WIPO, 2019). Sementara itu, paten merupakan perlindungan hukum yang diberikan oleh negara kepada seseorang atau institusi yang pertama kali mengembangkan teknologi dan wajib menerapkannya secara komersial (Kusumadara, 2011). Dengan kata lain, hasil pengembangan teknologi atau rancangan riset juga dianggap sebagai kekayaan intelektual. Bahkan paten sebagai salah satu bentuk kekayaan intelektual, eksistensinya memiliki kontribusi penting dalam menghasilkan pengetahuan baru, dengan tidak mengecilkan peran bentuk-bentuk kekayaan intelektual lainnya, misalnya hak cipta dan merek.

Serupa dengan hibah dana riset atau kontrak riset, keberadaan paten bertujuan untuk mendorong atau menstimulus kegiatan riset dan pengembangan Iptek, hal ini merupakan salah satu dari berbagai cara di mana inventor dapat memperoleh manfaat ekonomi dari produk teknologi yang dihasilkan. Pada perkembangannya, kegiatan riset dan inovasi semakin diharapkan dapat memberikan solusi atas permasalahan atau tantangan yang dihadapi oleh masyarakat (Stilgoe dkk., 2013). Keberadaan perlindungan paten mendorong para periset atau inovator semakin menggunakan gagasan atau ide yang dimilikinya yang berkaitan dengan kebutuhan dan tantangan masyarakat, dan penciptaan manfaat bagi publik sebagai dasar untuk menciptakan atau menemukan teknologi baru.

Meskipun demikian, kekayaan intelektual memiliki sisi lain selain manfaat yang dihasilkannya sebagaimana telah disebut di atas. Perlindungan paten juga menciptakan ketidakpastian dalam kolaborasi riset dan pengembangan, yang dapat mengakibatkan ancaman penyalahgunaan pengetahuan yang tidak dilindungi, mengurangi daya tawar kerja sama, meningkatkan biaya untuk pembayaran royalti atas lisensi teknologi, dan menyebabkan berkurangnya kolaborasi riset yang pada gilirannya dapat menghambat proses produksi pengetahuan. Namun, di dalam perlindungan paten juga terdapat pengecualian dalam penggunaan paten tanpa melanggar hak pemegangnya dan tanpa wajib membayar royalti atas penggunaan suatu teknologi paten dengan justifikasi kondisi darurat kesehatan 
yang dinamakan "bolar provisions/exemption" (Correa, 2020).

Lebih lanjut, dalam menjawab tantangan dari aspek kekayaan intelektual, pada perkembangannya terdapat diskursus dan implementasi paradigma baru pertukaran data dan informasi dalam konteks kolaborasi riset, yang dinamakan open science. Open science merupakan suatu kultur ilmiah di kalangan ilmuwan dalam bentuk praktik membagikan hasil riset, data, dan informasi yang dihasilkannya secara terbuka kepada publik (Bartling \& Friesike, 2014). Praktik membuka data ini dapat menghasilkan manfaat: dapat menjadi katalisator kolaborasi riset baru, meningkatkan kepercayaan pada temuan/invensi teknologi, dan menghasilkan jejaring teknologi yang erat di antara para peneliti dan pemangku kebijakan lainnya. Selain itu, ilmuwan mendapatkan keuntungan karena membuat pekerjaan lebih mudah dilaksanakan untuk dibagikan, dan komunitas ilmiah memperoleh keuntungan karena tersedianya data untuk kebutuhan verifikasi dan validasi hasil riset serta membuat penemuan baru. Dengan demikian, eksistensi open science pada dasarnya bertujuan untuk mengakselerasi kolaborasi antar periset atau komunitas ilmiah dengan mempraktikkan sharing data, ilmu pengetahuan, dan teknologi.

Terdapat tiga elemen penting dalam implementasi paradigma open science yang mencakup hal-hal sebagai berikut: (a) proses ilmiah, yang mencakup prosedur konseptualisasi dan pendanaan, pengumpulan data, eksperimen dan analisis, publikasi, diseminasi, dan penilaian dampak hasil riset; (b) aktor kunci/pemangku kepentingan, yaitu peneliti, pemerintah, lembaga pendanaan, badan amal dan yayasan, masyarakat, universitas dan lembaga riset publik, swasta/bisnis, penerbit, infrastruktur riset dan perpustakaan; dan (c) dijitalisasi, yaitu penggunaan teknologi informasi dalam rangka mendiseminasikan ilmu pengetahuan dan teknologi (Dai dkk., 2018).

\section{Urgensi kolaborasi riset}

Berkaitan erat dengan kolaborasi riset, hal yang menajdi perhatian utama adalah aktor yang melaksanakannya, yaitu para peneliti dan perekayasa. Aparatur Sipil Negara (ASN) yang menjadi peneliti dan perekayasa (SDM litbang) berdasarkan data mutakhir adalah sebesar 11.269 orang sebagaimana dapat terlihat pada Gambar 1 dan Tabel 1 di bawah ini. 


\section{Journal Publicuho}

ISSN2621-1351 (online), ISSN 2685-0729 (print)

Volume 4 Number 3 (August - October), 2021 pp. 820-833

Accredited SINTA SK.NOMOR 28/E/KPT/2019

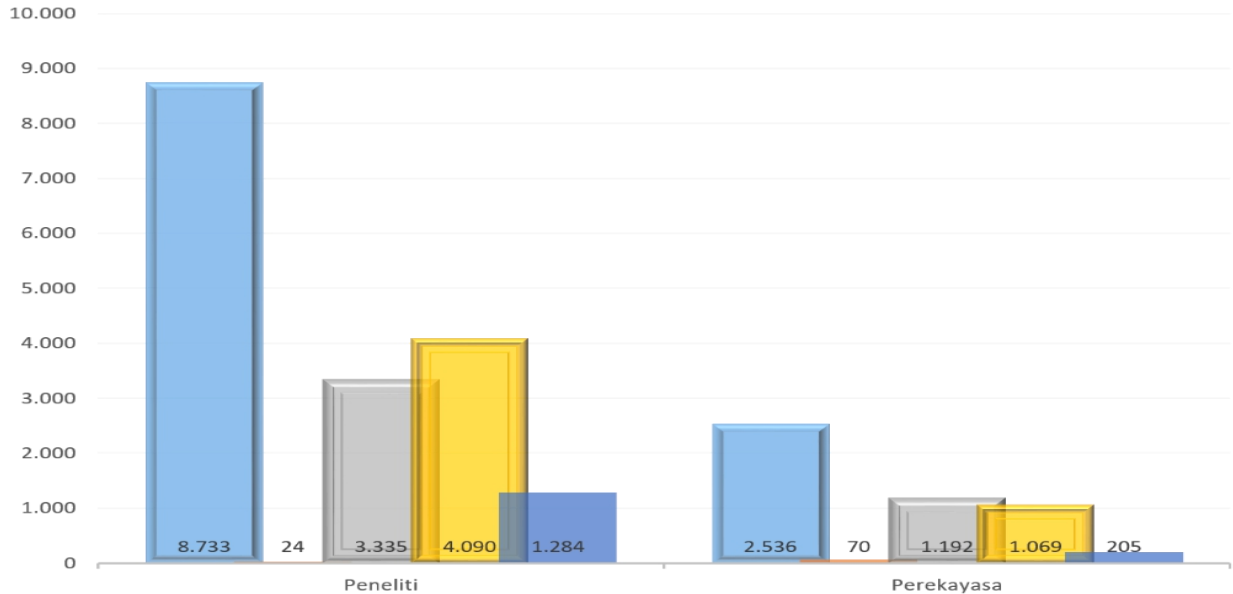

Gambar 1. Jumlah Peneliti dan Perekayasa serta kualifikasi pendidikan (Sumber: Data diolah dari Laporan Kinerja (Kemenristek/BRIN, 2020))

Tabel 1. Data Sebaran SDM Penelitian dan Pengembangan yang Berkualifikasi S3

\begin{tabular}{|c|c|c|c|}
\hline SDM Litbang & Peneliti & Perekayasa & Jumlah \\
\hline SDM Litbang berkualifikasi S3 & 1.284 & 205 & 1.489 \\
\hline Jumlah SDM Litbang & 8.733 & 2.536 & 11.269 \\
\hline \multicolumn{2}{|c|}{ Persentase SDM Litbang Berkualifikasi S3 } & $13,21 \%$ \\
\hline
\end{tabular}

Sumber: Laporan Kinerja (Kemenristek/BRIN, 2020)

Berdasarkan data yang terpresentasikan pada Gambar 1 dan Tabel 1 dapat diketahui bahwa terdapat jumlah ASN peneliti dan perekayasa yang tersebar pada 42 Kementerian/Lembaga. Kualifikasi pendidikan para ASN SDM litbang tersebut berturut-turut, D3/D4 sebanyak 94 orang, S1 sebanyak 4527 orang, S2 sebanyak 5159 orang, dan S3 sebanyak 1489 orang. Dari sejumlah tersebut, para peneliti dan perekayasa yang menekuni riset dan pengembangan di bidang kesehatan terutama berkarier di Lembaga IImu Pengetahuan Indonesia, BPPT, Badan Tenaga Nuklir Nasional, Lembaga Biologi Molekuler Eijkman, dan Kementerian Kesehatan. Dengan demikian terdapat modal (human capital) dalam rangka pelaksanaan riset dan pengembangan apabila dikaitkan dengan konteks penanggulangan COVID-19.

Meskipun demikian, perkembangan mutakhir menunjukkan data yang dapat dikatakan tantangan bagi dunia riset dan pengembangan sains dan teknologi di Indonesia. Data Indeks Inovasi Global Tahun 2020 menunjukkan bahwa Indonesia masih berada pada posisi rangking ke-85 tertinggal dari negara-negara lain sebagaimana ditampilkan pada Gambar 2 dan Gambar 3 di bawah ini. 


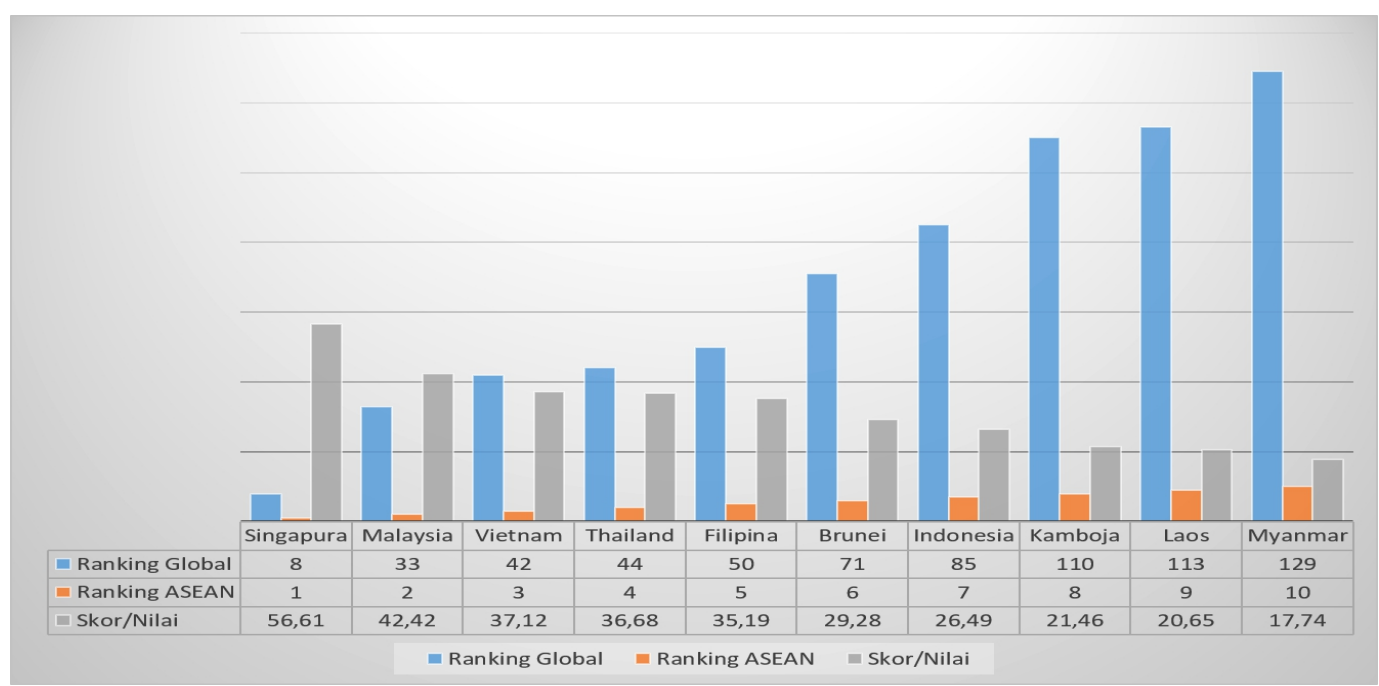

Gambar 2. Indeks Kualitas Inovasi Negara ASEAN 2020 (Sumber: Data diolah dari (WIPO et al., 2020)

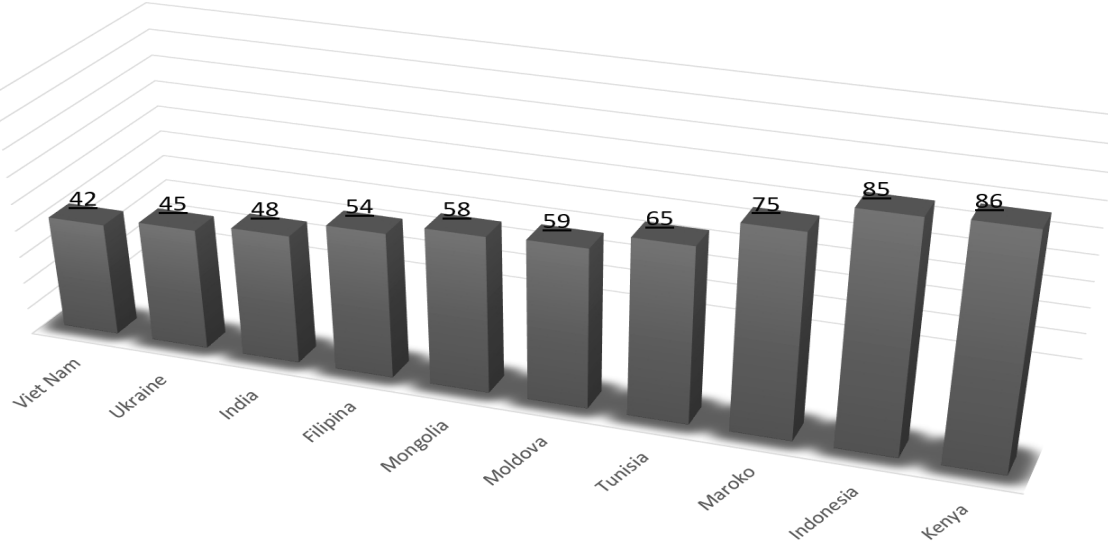

Gambar 3. Indeks Kualitas Inovasi Negara Berpendapatan Menengah Tahun 2020 (Sumber: Data diolah dari (WIPO, 2020))

Berdasarkan data yang terpresentasikan pada Gambar 2 dan Gambar 3, dapat diketahui bahwa saat ini Indonesia berada pada posisi ke-85 di dunia yang mana apabila dibandingkan dengan negara-negara jiran di ASEAN, posisi Indonesia menempati rangking ke-7 dengan skor 26,9. Indonesia telah tertinggal jauh dengan Singapura, bahkan dengan Vietnam yang notabene baru memulai pembangunan negaranya beberapa dekade terakhir. Selain itu terdapat data perbandingan lain, dalam deretan kategori negara-negara berpendapatan menengah, Indonesia menempati rangking 9 diantara 10 negara. Posisi Indonesia ini belum beranjak secara signifikan dari rangking lima tahun sebelumnya, yaitu ke97. Dengan demikian, melihat kondisi tersebut berarti masih terdapat pekerjaan rumah dalam rangka meningkatkan kualitas inovasi sehingga lebih kompetitif dengan negaranegara lain pada tataran global. 


\section{Journal Publicuho}

ISSN2621-1351 (online), ISSN 2685-0729 (print)

Volume 4 Number 3 (August - October), 2021 pp. 820-833

Accredited SINTA SK.NOMOR 28/E/KPT/2019

Open Access at:http://ojs.uho.ac.id/index.php/PUBLICUHO/index

DOI: 10.35817/jpu.v4i3.19670

Penilaian indeks inovasi global tersebut berdasarkan beberapa indikator. Salah satu indikatornya adalah kuantitas dan kualitas output riset dan pengembangan atau hasil riset. Pada Tabel 2 dan Tabel 3 menunjukkan data perbandingan output publikasi dan paten antara Indonesia dan negara-negara lain, baik yang berada di kawasan ASEAN maupun negara-negara maju lainnya.

Tabel 2. Peringkat Rangking Jurnal IImiah Negara ASEAN Tahun 2019

\begin{tabular}{|c|c|c|c|c|c|c|c|}
\hline Peringkat & Negara & Dokumen & $\begin{array}{c}\text { Dokumen } \\
\text { yang } \\
\text { dapat } \\
\text { dikutip }\end{array}$ & $\begin{array}{c}\text { Jumlah } \\
\text { Kutipan }\end{array}$ & $\begin{array}{c}\text { Mengutip } \\
\text { Sendiri }\end{array}$ & $\begin{array}{c}\text { Kutipan } \\
\text { per } \\
\text { dokumen }\end{array}$ & Indeks-H \\
\hline 32 & Singapura & 292.560 & 269.110 & 5.656 .862 & 632.326 & 19.34 & 535 \\
\hline 34 & Malaysia & 286.411 & 274.464 & 2.107 .306 & 533.423 & 7.36 & 281 \\
\hline 44 & Thailand & 173.133 & 168.248 & 2.043 .065 & 318.580 & 11.47 & 311 \\
\hline 48 & Indonesia & 110.610 & 106.501 & 600.569 & 113.900 & 5.43 & 214 \\
\hline 59 & Vietnam & 51.748 & 48.863 & 527.419 & 80.349 & 10.19 & 198 \\
\hline 68 & Filipina & 32.326 & 29.460 & 468.403 & 46.024 & 14.49 & 224 \\
\hline
\end{tabular}

Sumber: Laporan Kinerja (Kemenristek/BRIN, 2020)

Berdasarkan data yang terpresentasikan pada Tabel 2 dan Tabel 3, dapat diketahui bahwa untuk publikasi ilmiah, Indonesia menampati rangking 48 global dan ke-4 di ASEAN, di bawah Singapura, Malaysia, dan Thailand. Fakta yang menarik, meskipun secara kuantitas dokumen sebanyak 110.610 Indonesia lebih unggul dibandingkan Vietnam dan Filipina, namun pada indikator kutipan per dokumen lebih rendah dibandingkan dengan Vietnam dan Filipina. Selain itu h-indeks Indonesia juga masih berada pada posisi di bawah Filipina. Hal ini menunjukkan bahwa meskipun secara kuantitas Indonesia lebih unggul namun secara kualitas yang ditunjukkan dengan indikator pengutipan/sitasi dan h-indeks masih relatif belum unggul, dan hanya sedikit lebih unggul apabila dibandingkan dengan Vietnam. Disparitas yang cukup tinggi apabila dibandingkan dengan Singapura, Malaysia, dan Thailand. Selain itu, angka statistik output riset berupa paten juga demikian dengan indikator perbandingan produk domestik bruto (GDP). Dengan GDP sebesar 3.106 US \$, di atas Malaysia, Singapura, Thailand, Vietnam, dan Korea Selatan, kuantitas pendaftaran paten Indonesia masih di bawah Singapura dan Korea Selatan. Bahkan apabila dibandingkan dengan Thailand, Malaysia, dan Vietnam yang angka GDP-nya di bawah Indonesia, jumlah kuantitas paten Indonesia belum menunjukkan keunggulan komparatif yang signifikan. Dengan demikian, berdasarkan pembacaan atas data-data tersebut, dapat diketahui bahwa kualitas output kegiatan riset dan pengembangan di Indonesia masih membutuhkan perbaikan dan peningkatan. 
Tabel 3. Data Perbandingan Jumlah Pendaftaran Paten antara Indonesia dengan Negara lain

\begin{tabular}{|c|c|c|c|c|c|}
\hline No. & Negara & $\mathbf{2 0 1 7}$ & $\begin{array}{c}\text { GDP } \\
\text { (Constant } \\
\text { 2011 }\end{array}$ & $\mathbf{2 0 1 8}$ & $\begin{array}{c}\text { GDP } \\
\text { (Constant }\end{array}$ \\
\hline 1 & & & & $\mathbf{2 0 1 1}$ US\$) \\
\hline 2 & Indonesia & 9.303 & 2.954 & 9.754 & 3.106 \\
\hline 3 & Malaysia & 7.072 & 848 & 7.295 & 888 \\
\hline 4 & Singapura & 10.930 & 493 & 11.845 & 508 \\
\hline 5 & Thailand & 7.865 & 1.127 & 8.149 & 1.174 \\
\hline 6 & Vietnam & 5.382 & 590 & 6.071 & 631 \\
\hline 7 & China & 1.381 .594 & 21.148 & 1.542 .002 & 22.544 \\
\hline 8 & Jepang & 318.481 & 4.933 & 313.567 & 4.972 \\
\hline 9 & Korea Selatan & 204.775 & 1.850 & 209.992 & 1.899 \\
\hline & Amerika Serikat & 606.956 & 17.711 & 597.141 & 18.217 \\
\hline
\end{tabular}

Sumber: Laporan Kinerja (Kemenristek/BRIN, 2020).

Erat kaitannya dengan masalah kualitas output riset dan pengembangan tersebut, salah satu cara meningkatkan kualitas adalah dengan cara kolaborasi riset. Konteks penanggulangan COVID-19, dimana terdapat kebutuhan aktual yang mendesak untuk menemukan atau menciptakan teknologi kesehatan, praktik kolaboratif pendayagunaan sains dan teknologi menemukan urgensinya. Selain itu, praktik kolaborasi riset, terlebih lagi yang bersifat global dan melibatkan peneliti multidisiplin juga dapat dijadikan sarana alih teknologi dari institusi riset yang telah maju dalam riset dan pengembangan teknologi kesehatan, dan dalam konteks mutakhir dibutuhkan gerak cepat yang sinergis antar periset dan komunitas ilmiah sehingga pandemi tersebut dapat segera ditanggulangi dengan baik dengan adanya intervensi teknologi Kesehatan (Moradian et al., 2020). Dengan demikian, kolaborasi riset bersifat signifikan urgen untuk dilakukan dengan pertimbangan untuk peningkatan kapasitas dan kualitas riset melalui alih teknologi, terlebih dalam rangka penanggulangan pandemi COVID-19.

\section{Upaya strategis membangun kolaborasi riset}

Untuk membangun kolaborasi riset yang berdampak signifikan, baik bagi kemajuan ilmu pengetahuan dan teknologi maupun dalam rangka alih teknologi yang pada gilirannya meningkatkan kapasitas atau kualitas riset, dibutuhkan upaya strategis. Upaya strategis pertama yang dapat terpetakan adalah membangun jejaring kolaboratif dengan institusi kredibel. Tolok ukur atau indikator kredibel atau tidaknya suatu institusi dapat dilihat dari jumlah publikasi riset yang telah dihasilkan yang menunjukkan produktivitas dan performa suatu institusi riset (Birkle dkk., 2020). Dalam konteks topik riset dan pengembangan COVID19 terdapat data-data mutakhir yang menunjukkan hal tersebut sebagaimana ditunjukkan dalam Gambar 4 dan Tabel 4 di bawah ini. 


\section{Journal Publicuho}

ISSN2621-1351 (online), ISSN 2685-0729 (print)

Volume 4 Number 3 (August - October), 2021 pp. 820-833

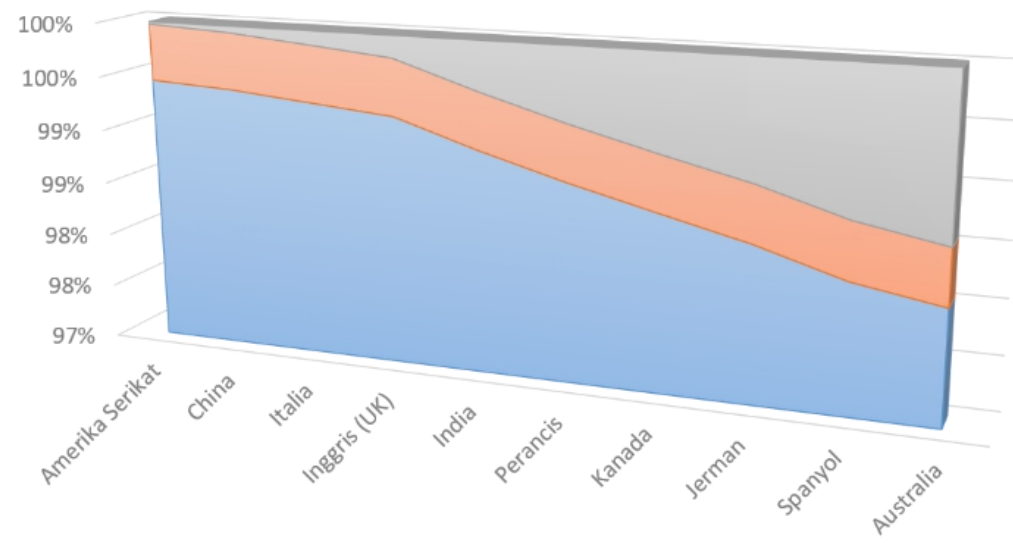

\begin{tabular}{|c|c|c|c|c|c|c|c|c|c|c|}
\hline & $\begin{array}{c}\text { Amerika } \\
\text { Serikat }\end{array}$ & China & Italia & $\begin{array}{c}\text { Inggris } \\
\text { (UK) }\end{array}$ & India & Perancis & Kanada & Jerman & Spanyol & Australia \\
\hline$\square$ Rangking & 1 & 2 & 3 & 4 & 5 & 6 & 7 & 8 & 9 & 10 \\
\hline$\square$ Persentase & 23,5 & 17,4 & 12,2 & 10,4 & 5,8 & 4,6 & 4,1 & 3,9 & 3,6 & 3,5 \\
\hline 口 Jumlah Publikasi & 4479 & 3310 & 2314 & 1981 & 1104 & 881 & 790 & 742 & 680 & 676 \\
\hline
\end{tabular}

Gambar 4. 10 Besar Negara Penghasil Publikasi Riset COVID-19 (Sumber: (Zyoud dan Al-Jabi, 2020))

Tabel 4. Peringkat 10 Besar Global Institusi Riset Penghasil Publikasi COVID-19

\begin{tabular}{|c|l|c|c|}
\hline No. & \multicolumn{1}{|c|}{ Institusi Riset } & Negara & Jumlah Publikasi (\%) \\
\hline 1 & $\begin{array}{l}\text { Huazhong University of Science } \\
\text { and Technology }\end{array}$ & China & $422(2.22)$ \\
\hline 2 & Tongji Medical College & China & $415(2.18)$ \\
\hline 3 & Harvard Medical School & Amerika Serikat & $331(1.74)$ \\
\hline 4 & $\begin{array}{l}\text { Inserm (French National Institute } \\
\text { of Health and Medical Research) }\end{array}$ & Perancis & $272(1.43)$ \\
\hline 5 & Università degli Studi di Milano & Italia & $258(1.35)$ \\
\hline 6 & University College London & Inggris (UK) & $237(1.24)$ \\
\hline 7 & $\begin{array}{l}\text { Università degli Studi di Roma La } \\
\text { Sapienza }\end{array}$ & Italia & $232(1.22)$ \\
\hline 8 & IRCCS Foundation Rome & Italia & $223(1.17)$ \\
\hline 9 & University of Toronto & Kanada & $210(1.10)$ \\
\hline 10 & University of Oxford & Inggris (UK) & $191(1.00)$ \\
\hline
\end{tabular}

Sumber: Data diolah dari (Dehghanbanadaki dkk., 2020)

Berdasarkan Gambar 4 dan Tabel 4, dapat diketahui informasi bahwa terdapat 10 besar negara penghasil publikasi riset COVID-19 berdasarkan peringkat adalah Amerika Serikat, China, Italia, Inggris (UK), India, Perancis, Kanada, Jerman, Spanyol, dan Australia. Relatif berbeda dengan data negara asal, dalam konteks institusi riset, justru institusi riset dari China 
menempati posisi pertama dan kedua, lalu diikuti Amerika Serikat, Perancis, Italia, Inggris, dan Kanada. Informasi ini menunjukkan sinyalemen calon mitra strategis untuk menjalin kolaborasi riset, dimana dapat mengakselerasi alih teknologi yang pada gilirannya menumbuhkan peningkatan kualitas riset dan pengembangan sains dan teknologi di bidang kesehatan.

Lebih lanjut, keberadaan institusi riset yang kredibel tidak cukup menjadi justifikasi strategis dalam membangun kolaborasi riset. Hal ini disebabkan, sebagaimana telah dijelaskan sebelumnya di atas bahwa terdapat kendala esensial dalam menjalin kolaborasi riset yakni kekayaan intelektual dalam konteks perlindungan hak ekonomi. Untuk mengatasi permasalahaan ini dibutuhkan pendekatan dan implementasi paradigma open sciecne. Dalam konteks penanggulangan COVID-19, implementasi paradigma ini dibutuhkan guna mengakselerasi interaksi dan kolaborasi riset, dan menjadi sarana untuk berbagi pengetahuan, data, dan informasi paten mutakhir antar periset dan perekayasa secara global (Cattani, 2020). Hal lain yang dapat menjadi justifikasi praktik open science yang merupakan prinsip bolar exemptions, dimana terdapat pengecualian dari kualifikasi pelanggaran kekayaan intelektual apabila tujuan dari penggunaan tersebut adalah dalam rangka riset dan pengembangan tanpa tujuan komersil terlebih dalam konteks terjadinya masalah kesehatan publik (Wested \& Minssen, 2019). Penerapan prinsip ini kemudian dapat menjadi landasan praktik rekayasa balik (reverse engineering), yaitu praktik pengungkapan suatu pengetahuan dari teknologi yang telah ada sebelumnya guna dimodifikasi menjadi suatu teknologi baru maupun invensi baru. Di bidang kesehatan terdapat beberapa produk teknologi yang dapat muncul dari praktik ini, antara lain alat kesehatan, obat-obatan, peptida terapeutik dengan cara mempelajari desain produk dan lalu memodifikasinya (Bhatti dkk., 2018). Dengan demikian, dapat diketahui bahwa selain faktor institusi riset yang kredibel sebagai katalisator alih teknologi, dibutuhkan juga praktik pengecualian komersialisasi kekayaan intelektual guna akselerasi kolaborasi riset.

Berdasarkan uraian temuan dari penulisan ini, penulis mensintesiskan beberapa hal yang menjadi faktor determinan dalam upaya membangun kolaborasi riset menjadi suatu rekomendasi strategi yang hasil akhirnya adalah kapasitas atau kesiapan menghadapi krisis kesehatan berbasis kolaborasi iptek sebagaimana dilustrasikan pada Gambar 5. 


\section{Journal Publicuho}

ISSN2621-1351 (online), ISSN 2685-0729 (print)
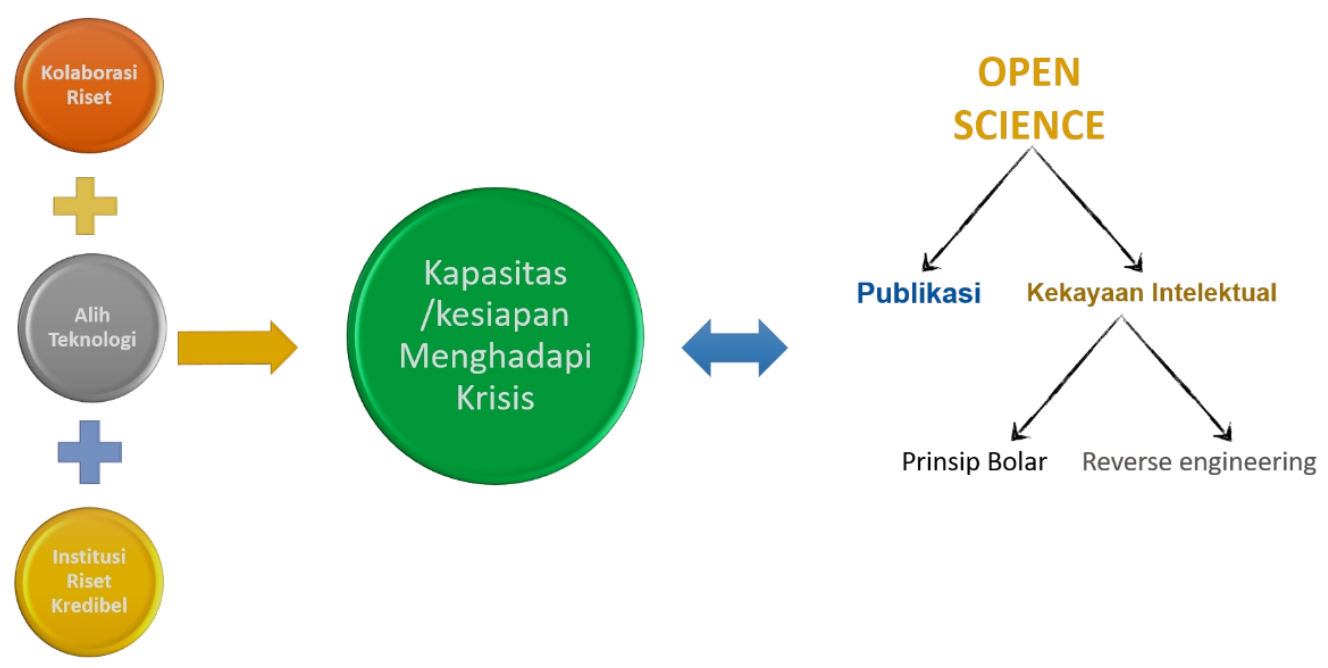

Gambar 5. Strategi Peningkatan Kapasitas Iptek Menghadapi Krisis (Sumber: Sintesis Hasil Riset)

Berdasarkan Gambar 5 dapat diterangkan bahwa dalam rangka mencapai output kapasitas atau kesiapan dalam menghadapi krisis-tidak sekadar dalam konteks COVID-19tetapi juga strategi dalam menghadapi kondisi di masa depan setidak-tidaknya dibutuhkan dua hal. Pertama, kolaborasi riset yang didukung adanya alih teknologi dan dilaksanakan bersama mitra yang berasal dari institusi riset kredibel yang mana dapat menunjang akselerasi alih teknologi. Kedua, proses kolaborasi tersebut membutuhkan daya dukung yang terletak pada implementasi paradigm open science atas publikasi ilmiah, paten, data dan informasi hasil riset. Dengan adanya paradigma ini berkontribusi pada implementasi praktik reverse engineering yang berlandasrkan pada prinsip bolar. Dengan adanya penerapan langkah-langkah ini pada gilirannya dapat meningkatkan kualitas riset dan pengembangan pada suatu sisi, dan di sisi lain terdapat katalisator untuk mengurai hambatan faktor teknislegal sehingga mendorong kolaborasi sinergis antar peneliti dan perekayasa secara global.

\section{KESIMPULAN}

Berdasarkan pembahasan di atas, dari hasil studi ini diperoleh dua hal, yaitu: pertama, bahwa kolaborasi riset dalam rangka alih teknologi signifikan urgen untuk dilaksanakan dengan pertimbangan bahwa kondisi mutakhir menunjukkan indeks inoavsi Indonesia masih belum mampu menandingi negara-negara lainnya, bahkan dalam lingkup kawasan ASEAN yang terlihat dari indikator publikasi ilmiah dan inovasi atau kekayaan intelektual yang masih rendah. Dengan adanya kolaborasi riset dapat mendorong para peneliti dan perekayasa mendapatkan pengetahuan baru mengenai teknologi di bidang kesehatan.

Kedua, upaya strategis yang dapat dilakukan adalah berkolaborasi dengan para peneliti dan perekayasa dari institusi riset yang kredibel dalam riset dan pengembangan teknologi di bidang kesehatan. Indikator kredibel atau tidak suatu institusi riset terlihat dari kualitas dan 
kuantitas publikasi ilmiah yang dihasilkan serta paten teknologi. Selain itu, institusi riset tersebut telah menerapkan kebijakan open science yang mana akan sangat membantu proses alih teknologi dalam kerangka kolaborasi riset tanpa terkendala masalah kekayaan intelektual yang pada umumnya menghambat pelaksanaan pengembangan ilmu pengetahuan dan teknologi karena sifat komersialnya atau aspek ekonomi.

Berdasarkan dua temuan tersebut, penulis merekomendasikan suatu strategi untuk membangun kesiapan kapasitas sumber daya manusia peneliti dan perekayasa dalam konteks menghadapi krisis kesehatan berbasis kolaborasi riset. Pada sisi kolaborasi riset terdapat tiga elemen penting, yaitu pemanfaatan jejaring kolaboratif, alih teknologi, dan interaksi dengan institusi riset yang kredibel. Guna mendukung kolaborasi riset ini atau dengan kata lain faktor pendorong, yaitu implementasi open science atas hasil riset, baik berupa publikasi maupun kekayaan intelektual yang mana dengan adanya keterbukaan berbasis pada prinsip bolar exemptions dan praktik reverse engineering tersebut dapat mengakselerasi riset dan pengembangan di bidang kesehatan yang pada gilirannya memunculkan inovasi dan pengetahuan baru yang berkontribusi bagi penanggulangan krisis kesehatan, baik dalam konteks COVID-19 maupun di masa depan.

Sesuai dengan hasil yang diperoleh dari penelitian ini, diharapkan pada penelitian selanjutnya dapat menyusun suatu alternatif strategi yang dapat mengakselerasi kapasitas SDM berbasis kolaborasi riset antar jejaring institusi riset agar bermanfaat dan berdayaguna dalam menghadapi krisis kesehatan seperti saat ini, serta dapat digunakan sebagai rekomendasi di masa depan. Untuk itu, penelitian selanjutnya dapat lebih difokuskan pada data kekayaan intelektual terkait penelitian dan pengembangan mengenai atau terkait COVID-19, sehingga dapat menghasilkan informasi yang lebih baru (up-to-date).

\section{REFERENSI}

Bartling, S., \& Friesike, S. (2014). Opening Science - The Evolving Guide on How the Web is Changing Research, Collaboration and Scholarly Publishing.

Bhatti, A., Syed, N. A., \& John, P. (2018). Chapter 5 - Reverse Engineering and Its Applications (D. Barh \& V. B. T.-O. T. and B.-E. Azevedo, Eds.; pp. 95-110). Academic Press. https://doi.org/https://doi.org/10.1016/B978-0-12-804659-3.00005-1

Birkle, C., Pendlebury, D., Schnell, J., \& Adams, J. (2020). Web of Science as a data source for research on scientific and scholarly activity. Quantitative Science Studies, 1, 1-14. https://doi.org/10.1162/ass_a_00018

Bryman, A., \& Burgess, R. G. (2002). Analyzing Qualitative Data. New York: Routledge.

Campbell, C. D., Challen, B., Turner, K. L., \& Stewart, M. I. (2020). \#DryLabs20: A New Global Collaborative Network to Consider and Address the Challenges of Laboratory Teaching with the Challenges of COVID-19. Journal of Chemical Education, 97(9), 3023-3027. https://doi.org/10.1021/acs.jchemed.0c00884 


\section{Journal Publicuho}

ISSN2621-1351 (online), ISSN 2685-0729 (print)

Volume 4 Number 3 (August - October), 2021 pp. 820-833

Accredited SINTA SK.NOMOR 28/E/KPT/2019

Open Access at:http://ojs.uho.ac.id/index.php/PUBLICUHO/index DOI: 10.35817/jpu.v4i3.19670

Cattani, M. (2020). Global coalition to accelerate COVID-19 clinical research in resourcelimited settings. The Lancet, 395(10233), 1322-1325. https://doi.org/https://doi.org/10.1016/S0140-6736(20)30798-4

Correa, C. (2020). Trade related aspects of intellectual property rights: a commentary on the TRIPS agreement. Oxford University Press.

Dai, Q., Shin, E., \& Smith, C. (2018). Open and inclusive collaboration in science. OECD Science, Technology and Industry Policy Papers, 1-29. http://dx.doi.org/10.1787/2dbff737-en

Dehghanbanadaki, H., Seif, F., Vahidi, Y., Razi, F., Hashemi, E., Khoshmirsafa, M., \& Aazami, H. (2020). Bibliometric analysis of global scientific research on Coronavirus (COVID-19). Medical Journal of the Islamic Republic of Iran, 34, 354-362. https://doi.org/10.34171/mijiri.34.51

Friedman, J., \& Silberman, J. (2003). University Technology Transfer: Do Incentives, Management, and Location Matter? The Journal of Technology Transfer, 28, 17-30. https://doi.org/10.1023/A:1021674618658

Kemenristek/BRIN. (2020). Laporan Kinerja Tahun 2020.

Kusumadara, A. (2011). Pemeliharaan dan Pelestarian Pengetahuan Tradisional dan Ekspresi Budaya Tradisional Indonesia: Perlindungan Hak Kekayaan Intelektual dan Non-Hak Kekayaan Intelektual. JURNAL HUKUM IUS QUIA IUSTUM, 18, 20-41. https://doi.org/10.20885/iustum.vol18.iss 1.art2

Maluleka, J., Onyancha, O., \& Ajiferuke, I. (2016). Factors influencing research collaboration in LIS schools in South Africa. Scientometrics, 107. https://doi.org/10.1007/s11192-016$\underline{1846-0}$

Moradian, N., Ochs, H., Sedikies, C., Hamblin, M., Camargo, C., Martinez, J., Biamonte, J., Abdollahi, M., Torres, P., Nieto, J., Ogino, S., Seymour, J., Abraham, A., Cauda, V., Gupta, S., Ramakrishna, S., Sellke, F., Sorooshian, A., Hayes, A. W., \& Rezaei, N. (2020). The urgent need for integrated science to fight COVID-19 pandemic and beyond. Journal of Translational Medicine, 18, 205. https://doi.org/10.1 186/s12967-020-02364-2

Nonaka, I., \& Toyama, R. (2007). Why do firms differ? : the theory of the knowledge-creating firm. In Knowledge creation and management: new challenges for managers (pp. 1331). Oxford University Press.

Satgas-Covid19. (2020). https://www.covid 19.go.id/. Https://Www.Covid19.Go.Id/.

Stilgoe, J., Owen, R., \& Macnaghten, P. (2013). Developing a framework for responsible innovation. Research Policy, 42(9), 1568-1580. https://doi.org/https://doi.org/10.1016/j.respol.2013.05.008

Wested, J., \& Minssen, T. (2019). An Update on Research- \& Bolar Exemptions in the U.S. and Europe: Unsolved Questions and New Developments in an Increasingly Important Area of Law. 2019, 168-183.

WHO. (2020). Numbers at a glance. Https://Www.Who.Int/Emergencies/Diseases/NovelCoronavirus-2019?

WIPO. (2019). Intellectual property definition. Https://Www.Wipo.Int/about-Ip/En/.

WIPO, University, C., \& INSEAD. (2020). The Global Innovation Index 2020: Who Will Finance Innovation? Ithaca, Fontainebleau, and Geneva.

Zyoud, S., \& Al-Jabi, S. (2020). Mapping the situation of research on coronavirus disease-19 (COVID-19): a preliminary bibliometric analysis during the early stage of the outbreak. BMC Infectious Diseases, 20. https://doi.org/10.1186/s12879-020-05293-z 